thought that we were trying to find challengers to run against their boss. When we assured them that we were political science professors, that we were conducting our study in 200 randomly selected districts, that we were contacting equal numbers of activists in both political parties, and that we had no interest in stimulating anyone to run, virtually all callers were completely mollified. Some even wished us luck in our study and expressed an interest in seeing our results when they became available.

\section{Representative Clay's Response to the CES}

One member's staffers were not persuaded. After we had several telephone conversations with his staff, Representative Bill Clay (DMO), issued a press release on June 17, 1997, entitled "Federal Dollars Used to Recruit Congressional Candidates." In the six-paragraph re- lease, Mr. Clay called for suspending the study, expressing "outrage ... that our tax dollars are being wasted on a study to find candidates to run for office." Clay asserted that "there is never any shortage of good and qualified people who feel they could serve in Congress" and that Maisel and Stone "have refused to answer inquiries by congressional committee staff about the details of this socalled scientific study." He went on to say, "I remember the federal government spending taxpayer dollars to fund the Tuskegee experiment in the interest of science. We have learned that only full, thorough, and immediate disclosure of the facts can reveal whether a study is scientific." In a letter dated June 24, 1997, Clay and three other House members requested an investigation of our project by the Inspector General of the National Science Foundation and by the General Accounting Office. Following Congressman
Clay's press release, the press was on to the story, our phones rang non-stop, and stories and editorials appeared in newspapers nationwide.

In our conversations with Congressman Clay's staff, we answered every question they asked, except one: They requested the identity of the congressional districts in our sample so they could "verify" that the sample was randomly selected. The question of whether our districts were randomly selected was reasonable, since random selection would have been inconsistent with a partisan political agenda targeting specific members of Congress and recruiting individuals to run against them. As we explained to Representative Clay's aides, we kept the identity of our districts confidential because releasing them would be tantamount to identifying our respondents in some districts, where we took a census of all eligible individuals in the informant stage of the

\title{
APSA Council Reaffirms Freedom and Integrity of Research
}

At its September meeting, the APSA Council reaffirmed the Association's current guidelines regarding the responsibilities of scholars and funding sources toward the integrity and freedom of social science research in a democratic society. The Council's actions were precipitated by the controversy surrounding Representative Bill Clay's (D-MO) unsubstantiated allegations challenging the scientific integrity and objectivity of the Candidate Emergence Study, carried out in 1997 by political scientists Sandy Maisel of Colby College and Walt Stone of the University of Colorado. Maisel and Stone give an account of their unfortunate saga in the following essay. The Candidate Emergence Study was a peer-reviewed, scientific investigation, funded by the Political Science Program of the National Science Foundation. Informants chosen from a random, representative sample of congressional districts were asked to identify potential candidates. The potential candidates were then surveyed by mail. Upon learning of the study, several members of Congress questioned the study's objectivity, leading the House of Representatives to approve a reduction in NSF appropriations as a show of their displeasure with the science agency for funding this type of political science research. The provision was dropped in conference.

The APSA Council, with the assistance of the Committee on Professional Ethics, Rights and Freedoms, chaired by Matthew Moen, and the chairs of the Committee on Education and Professional Development and the Research Support Advisory Committee, reaffirmed APSA's guidelines on the integrity of political science research. The guidelines were first articulated in the "Bernstein Report" of 1967. The Council's statement and additions to the Association's Guide to Professional Ethics are reproduced below.

$$
\begin{aligned}
& \frac{\text { A Statement of the American Political }}{\text { Science Association }} \\
& \text { "FREEDOM AND INTEGRITY OF RESEARCH: } \\
& \text { THE RESPONSIBILITIES OF SCHOLARS AND } \\
& \text { FUNDING SOURCES IN A DEMOCRATIC SOCIETY" }
\end{aligned}
$$

Preface

Political scientists have ongoing concerns about the relationship between research and funding, especially in the area of confidentiality of sources. Scholars must be able to conduct research in our democratic sociely, free from pressure to disclose properly contidential information.

In 1967, the American Political Science Association created a Committee on Professional Standards and Responsibilities, which issued a report providing guidelines for professional conduct by political scientists. One element of that report warned scholars of possible complications if they accepted funding from sources lacking a commitment to dispassionate scholarship; the burden was placed primarily upon the scholar rather than the funding source. Yet, those who fund research- particularly public institutions and agencies - also have professional obligations. They need to recognize the vital contribution that political scientists make by studying democratic institutions, and they should not impede legitimate scholarly inquiry. 
study. In our proposal and elsewhere, we had already fully described the procedures we followed to identify the population of district informants. If we disclosed our districts, it would have been a simple matter to track these people down in many districts, and their anonymity as respondents to our survey would have been compromised.

Because of the legitimacy of the question about random selection, however, we prepared a detailed analysis of the districts in our sample, comparing them with districts not included in the sample. We sent a copy of this memo to Congressman Clay and to every Hill office that had raised questions about the study. On a wide range of indicators, there were no significant differences between the sample districts and the non-sample districts, which is exactly what is expected of a random sample.
With the controversy mounting, we welcomed the opportunity to answer Clay's charges through the Inspector General's (IG) investigation of the CES. The Office of the Inspector General was created to investigate charges of scientific fraud and programmatic malfeasance. Thus, its officers were ideally suited to determine whether we were acting fraudulently by recruiting candidates with NSF money, as Clay continued to insist.

We hoped that the Inspector General's investigation would lay to rest the concerns expressed by Congressman Clay's office. We cooperated fully with the IG in every aspect of their scrutiny of our project. Their investigators interviewed us, the program officers at NSF, and a variety of others involved in the review and award of the grant. They reviewed the design of the research to be certain it conformed with what we proposed, and they examined the letters, questionnaires, and other documents we used in contacting our respondents. As requested by Congressman Clay and his colleagues, the IG filed its report on July 9,1997 , in advance of the floor debate on the 1998 NSF appropriations bill. After describing the peerreview process used by the Political Science Program to award the grant and the academic nature of the questions the proposal was designed to answer, the report concluded: "The research being conducted in the Candidate Emergence Study is fully consistent with the research that was proposed to NSF and that the NSF chose to fund. The cover letter accompanying the survey questionnaire is also consistent with the purposes of the study that Dr. Stone and Dr. Maisel proposed" (National Science Foundation 1997, 6).

\section{Reaffirming Current Guidelines}

The Guide to Professional Ethics in Political Science provides a clear and forceful statement about a researcher's obligation to maintain confidentiality of sources, balanced with restraint in making claims of confidentiality and with disclosure of nonconfidential sources (Section A.6). These principles endure and deserve reiteration.

The Guide to Professional Ethics in Political Science also notes that "financial sponsors of research should avoid actions that would call into question the integrity of American academic institutions as centers of independent teaching and research" (Section A.1.3); it mentions that "the grantor shall not impose any restriction on or require any clearance of research methods, procedures, or content" (Section A.1.5). These provisions are worth restating to remind all funding sources that they should refrain from interfering with legitimate scholarly inquiry, even if a research product is unsettling to its sponsors. Scholars and funding sources alike must recognize and defend these principles of research, particularly given the substantial reliance of the academy on external sources of funding.

The American Political Science Association reaffirms its enduring commitment to confidentiality of sources and to uncompromised and independent scholarly inquiry.

\section{New Language}

Beyond reaffirmation of important principles already in place, the following revisions to the Guide to Professional Ethics in Political Science are hereby adopted by the APSA Council. These revisions will be distributed throughout the political science community, and, with the assistance of the Consortium of Social Science Associations, to the broader community of social and behavioral scientists.
A.1.8. Members of public institutions or agencies should not interfere with disinterested scholarly investigation of their actions, processes, or functions. Public institutions should recognize the value of scholarship and acknowledge that interference with bona fide scholarship is contrary to the core values on which our democratic institutions are predicated.

A.1.9. Governmental and nongovernmental officials and agencies that fund scholarly research should understand that scholars have a professional obligation to protect the identity of confidential sources of information or data that is developed in the course of researching institutions, agencies, or persons. Funding entities should help scholars fulfill their obligations, not impede them.

\section{Council Supports Maisel and Stone}

In addition to promulgating these research guidelines, the APSA Council formally placed itself behind Maisel and Stone. It was the unanimous sense of the Council that attempts by public officials to interfere in the Candidate Emergence Study was a serious breech of the guidelines governing the freedom and integrity of political science research. The Council also expressed its confidence in the project's principal investigators, Sandy Maisel and Walt Stone, and support for their efforts to uphold the research guidelines. 